\title{
Low concentration of morphine protects against cell death, oxidative stress and calcium accumulation by nicotine in PC12 cells
}

\author{
Amini $\mathrm{K}^{1}$, Zhaleh $\mathrm{H}^{2}$, Tahvilian $\mathrm{R}^{3}$, Farnia $\mathrm{V}^{2}$ \\ Department of Biology, Faculty of Sciences, Razi University, Kermanshah, Iran. \\ hossain_jale@yahoo.com
}

\begin{abstract}
OBJECTIVE: Nicotine causes cell death in many cell lines. Morphine at low concentrations has protective effects against cell death. We investigated the effects of low concentration of morphine on nicotine-induced cell death in PC12 cells.

MATERIALS AND METHODS: PC12 are cells that grow in DMEM culture medium. Cell viability was detected by MTT test and cells cytotoxicity was measured by LDH test. The activity of caspase- 3 was diagnosed by the caspase activity colorimetric assay kit, and detection of mitochondrial membrane potential was confirmed by rhodamine 123 and TUNEL test was performed for DNA fragmentation detection. The fura-2 AM and also rhod 2-AM was used for measurement of intracellular calcium $\left(\mathrm{Ca}^{2+}\right)$ ic and mitochondrial calcium $\left(\mathrm{Ca}^{2+}\right) \mathrm{m}$ and finally, measurement of antioxidant enzyme activities was assessed.

RESULTS: The low concentration of morphine increased cell viability and suppressed cell cytotoxicity, cell death and the formation of mitochondrial membrane potential compared to nicotine treated cells. It also reduced the intracellular calcium $\left(\mathrm{Ca}^{2+}\right)$ ic and mitochondrial calcium $\left(\mathrm{Ca}^{2+}\right) \mathrm{m}$ concentration, respectively.

CONCLUSION: Morphine as a pain reducer drug, in low concentrations, can protect PC12 cells from nicotineinduced cell death (Fig. 7, Ref. 59). Text in PDF www.elis.sk.

KEY WORDS: morphine, nicotine, apoptosis, cell death.
\end{abstract}

\section{Introduction}

Nicotine is a nitrogenous alkaloid compound, which is found in tobacco plant and acts as an activator in most nicotine acetylcholine receptors as well as antagonists in a few of these receptors (1-3). Also, it can stimulate the release of many important chemical messengers such as: dopamine, acetylcholine, epinephrine, norepinephrine, serotonin, beta-endorphin, and arginine vasopressin (4-6). Epinephrine release leads to an increased heart rate, blood pressure, respiration and blood glucose levels (7). Nicotine enhances weight loss, is associated with cardiovascular and atherosclerosis diseases. Studies of animals and in vitro studies indicate that nicotine has an apoptotic inhibitory function and from the other side it can enhance angiogenesis (8-10).

Long-time consumption of nicotine has destructive effects on the nervous, urine, digestion and circulatory systems as well as organs like the kidney, liver, intestine, stomach, and brain, which

${ }^{1}$ Department of Biology, Faculty of Sciences, Razi University, Kermanshah, Iran, ${ }^{2}$ Substance Abuse Prevention Research Center, Kermanshah University of Medical Sciences, Kermanshah, Iran and ${ }^{3}$ Pharmaceutical Sciences Research Center, School of Pharmacy, Kermanshah University of Medical Sciences, Kermanshah, Iran

Address for correspondence: $\mathrm{H}$. Zhaleh, $\mathrm{PhD}$, Kermanshah University of Medical Sciences, Kermanshah, Iran. is among them, the central nervous system and especially the brain structures, more important (11-13). For example, it can enhance the CYP2E1 expression of cortical pyramidal neurons and cerebellar Purkinje cells, which may increase the production of Reactive oxygen species (ROS) and thereby damage brain tissue. Previous studies showed that rodents treated by nicotine lost a significant amount of white matter (14-16). Gabriel Olaiya Omotoso et al, has shown that Moringa oleifera could prevent nicotine-induced cerebellar injury in Wistar rats (17).

Morphine is known as an opioid pain reliever drug, which acts as a mu opioid receptor signaling agonist. Several studies on morphine show different roles of this substance in the cellular cycle, protection, and proliferation. Although some studies showed that morphine could cause apoptosis in immune, cancer, neuroblastoma, and nerve cells, some studies showed the opposite function of this substance in astrocytes that protects these cells against apoptosis (18-22). These opposite effects indicate an unclear morphine function in carcinogenesis. Therefore, morphine is a suitable candidate for further investigation in the carcinogenic process.

Because the most important function of morphine is in neurons and cancer cells, in this study, the effect of low concentration of morphine in the presence of high-dose nicotine was evaluated on $\mathrm{PC} 12$, the cell line of rat pheochromocytoma that was derived from the adrenal medulla (23). High-dose nicotine causes cell death in these cell lines, so in this study we aimed to measure parameters 
such as: cell viability, cell cytotoxicity, DNA fragmentation, mitochondrial and intracellular $\mathrm{Ca}^{2+}$ concentration, (.OH) generation and mitochondrial membrane potential to the investigation of possible morphine role in suppressing the effects of nicotine-induced death on PC12 cell line.

\section{Materias and methods}

\section{Cell culture}

$\mathrm{PC} 12$ cell were grown in $\mathrm{T}-25 \mathrm{~cm}^{2}$ tissue culture flasks by DMEM culture medium (Gibco). Additional supplementary compounds were added to the cell cultures such as: $10 \%$ fetal bovine serum (FBS, Gibco), $1 \%$ non-essential amino acid (NEAA, Sigma), 2mM L-glutamine (Sigma), $100 \mathrm{IU} / \mathrm{ml}$ penicillin (Sigma), and $100 \mu \mathrm{g} / \mathrm{ml}$ streptomycin (Sigma) at $37^{\circ} \mathrm{C}$ in $5 \% \mathrm{CO}_{2}$ Medium, once every two days.

\section{Cell treatment}

A day after the cell cultivation, we used PBS, $\mathrm{pH} 7.4$ for washing. Next seven treatments were selected including; control: culture medium, Treatment 1: $1 \mathrm{mM}$ nicotine, Treatment 2: $1 \mathrm{mM}$ nicotine and $1 \mathrm{pM}$ morphine, Treatment 3: $1 \mathrm{mM}$ nicotine and $10 \mathrm{pM}$ morphine, Treatment 4: $1 \mathrm{mM}$ nicotine and 100pnM morphine, Treatment 5: $1 \mathrm{mM}$ nicotine and $1 \mathrm{nM}$ morphine, Treatment 6: $1 \mathrm{mM}$ nicotine and 10nM morphine, and Treatment 7: $1 \mathrm{mM}$ nicotine and $100 \mathrm{nM}$ morphine. In the following, the cells were incubated at 37 ${ }^{\circ} \mathrm{C}$ with $5 \% \mathrm{CO} 2$ and were cultured in DMEM culture medium containing $0.2 \% \mathrm{BSA}$.

\section{Cell viability (\%) measurement (MTT assay)}

For cell viability quantification, MTT assay was performed as shown below: at first $15 \times 10^{3}$ cells were cultured to a 96 -well cell culture plates with different treatments media for 24 hours. Next , we added $5 \mathrm{mg} / \mathrm{mL}$ of MTT solution to each well by incubation for 3 hours. The supernatant from each well was removed again and $100 \mu \mathrm{L}$ of dimethyl sulfoxide (Sigma) was added at room temperature for $30 \mathrm{~min}$. For measurement of the optical density of each well, we used an enzyme-linked immunosorbent assay (ELISA) reader at 570 and $630 \mathrm{~nm}$.

\section{Cell cytotoxicity measurement}

Next, we measured cell cytotoxicity by LDH Cytoxicity Detection Kit (Roche, Germany). Further, $1 \times 10^{4}$ cells $/ \mathrm{mL}$ densities for $12 \mathrm{~h}$ were plated in 24 well culture plates, then the cells were cultured by different treatment media for $24 \mathrm{~h}$. LDH activity's colorimetery was measured by calculation of samples absorbance at 490 or 492 nm using an ELISA Reader (EL800; USA).

\section{Caspase-3 assay}

PC12 cells were cultured in the different treatment media. In this study, the caspase- 3 activity of lysates from treated cells was measured, using a plate reader, according to the caspase activity colorimetric assay kit (Bio-techne) manufacturer's protocol. We repeated each of the experiments twice and the results were collected from two separate experiments

\section{Detection of mitochondrial membrane potential (MMP)}

Rhodamine 123 is a cell permeable cationic fluorescence probe and was used for MMP measurement. For quantitative analysis, PC1 2 cells, $2 \times 10^{4}$ cells/well, were cultured and treated in different treatment media, and incubated for $30 \mathrm{~min}$ in the $37^{\circ} \mathrm{C}$ dark place by $1 \mu \mathrm{M}$ rhodamine 123 . In the following, the absorbance of samples at 488 excitation and $525 \mathrm{~nm}$ emission was measured by an ELISA Reader for calculating the cells absorbance. The references wavelength was longer than $630 \mathrm{~nm}$.

\section{Quantification of apoptosis incidence}

At first, we fixed all the cells in this study by $4 \% \mathrm{w} / \mathrm{v}$ paraformaldehyde in PBS, $\mathrm{pH}=7.4$ for $10 \mathrm{~min}$ at room temperature. Next, we used TUNEL (Terminal Uridine deoxynucleotidyl transferase dUTP Nick End Labeling) staining for identification of the apoptotic cells. In this regard we worked by an in situ cell death detection kit (Roche) on the base of manufacturer's protocol. TUNEL positive cells were counted under a fluorescent microscope (Olympus AX-70), in eight randomly selected fields from each culture. Apoptotic incidence refers to the ratio of apoptotic cells to the total cells.

\section{Measurement of $\left(\mathrm{Ca}^{2+}\right)$ ic and $\left(\mathrm{Ca}^{2+}\right) \mathrm{m}$}

In this study, we measured the intracellular $\left(\mathrm{Ca}^{2+}\right)$ ic and mitochondrial $\left(\mathrm{Ca}^{2+}\right) \mathrm{m}$ calcium concentration on the base of previous studies (24). The excitation wavelength was altered between 340 and $380 \mathrm{~nm}$, and the emission fluorescence was recorded at $510 \mathrm{~nm}$.

$\left(\mathrm{Ca}^{2+}\right)$ ic concentrations were calculated using the equation described by Grynkiewicz (25). Relative mitochondrial $\left(\mathrm{Ca}^{2+}\right) \mathrm{m}$ was measured with the fluorescent probe rhod 2-AM following methods described in articles (26).

\section{Measurement of antioxidant enzyme activities}

Antioxidant enzyme activities and protein damage assay were calculated on the base of previous studies (27). Fluorescence (Ex. $490 \mathrm{~nm}$ and Em. $525 \mathrm{~nm}$ ) was visualized using a fluorescence microscope.

\section{Results}

\section{Cell culture}

\section{Cell viability (\%)}

$24 \mathrm{~h}$ after the exposure of different concentrations of morphine and high-concentration of nicotine, the cell viability was measured by MTT assay. As shown in Figure 1, control treatment showed us $99 \%$ of cell viability. Cell viability was $0 \%$ for treatment 1 and all of the cells were dead. The results showed that the viability of the cells in the 2-7 treatment media decreased compared to the control cells, significantly $(\mathrm{p}<0.05)$. Also, the cell viability increased in treatments 2-7 in comparison with the treatments 1 $(\mathrm{p}<0.05)$. The lowest and highest cell viability was for treatment 1 and treatment 2 , respectively $(\mathrm{p}<0.05)$. The lowest and highest cell viability was for treatment 1 and treatment 2 , respectively (Fig. 1) $(\mathrm{p}<0.05)$. 


\section{6-262}

\section{Cell cytotoxicity (\%)}

LDH assay was used for cell cytotoxicity measurement $24 \mathrm{~h}$ after exposure of different concentrations of morphine and nicotine. Although control treatment showed us $2 \%$ of cell cytotoxicity as shown in Figure 2, cell cytotoxicity was $100 \%$ for treatment 1 and all of the cells were dead. The results showed that cytotoxicity of the cells in the 2-7 treatment media increased compared to the control cells, significantly $(\mathrm{p}<0.05)$. Also, the cell cytotoxicity decreased in treatments 2-7 in comparison with treatments $1(\mathrm{p}<$ $0.05)$. The highest and lowest cell cytotoxicity was in treatment 1 and treatment 2, respectively (Fig. 2) $(\mathrm{p}<0.05)$.

\section{Cell death index}

After $24 \mathrm{~h}$, the cell death index was measured by TUNEL assay. Control treatment showed us $1 \%$ of the cell cytotoxicity in Figure 3 . In the case of treatment 1 , cell cytotoxicity was $100 \%$ and all of the cells were dead. The results showed that the cell deaths in the 2-7 treatment media increased compared to the control cells, significantly $(\mathrm{p}<0.05)$. Also, cell death decreased in treatments 2-7 in comparison with treatment 1 (Fig. 3) $(\mathrm{p}<0.05)$.

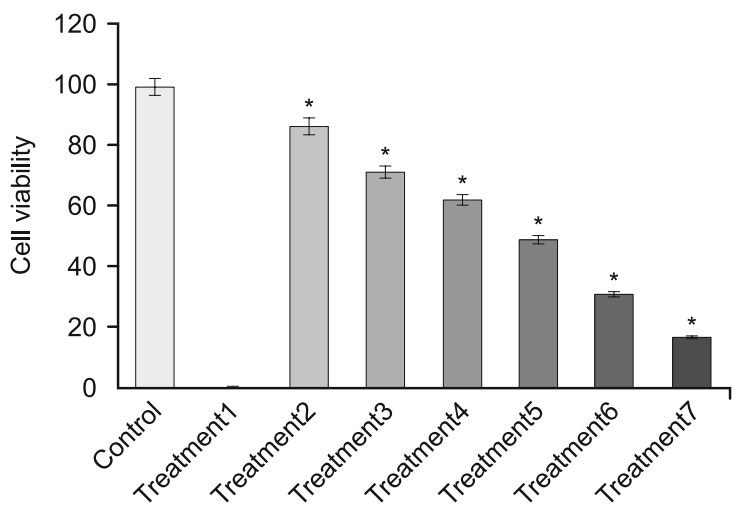

Fig. 1. The effects of different treatments on the cell viability of PC12 cells. All data represented as the mean \pm SEM $(p<0.05)$.

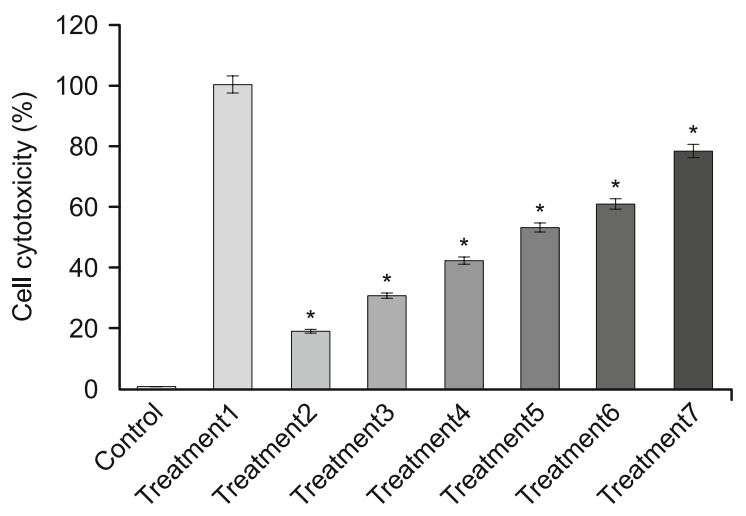

Fig. 2. The effects of different treatments on the cell cytotoxicity on cells. All data represented as the mean \pm SEM $(p<0.05)$.

\section{Caspase-3 assay}

Caspase-3 activation is a sign of apoptosis, which is eventually mediated by many caspases involved in this process. Furthermore, our results indicated that 2-7 treatments were increased in caspase- 3 activity, after $24 \mathrm{~h}$, compared to the control treatment ( $\mathrm{p}<$ $0.05)$. The lowest caspase- 3 activation was in control cells, which was lower than in other treatments (treatments $1-7)(\mathrm{p}<0.05)$. Caspase- 3 activation in treatments $2-7$ was lower compared to the treatment 1 , significantly $(\mathrm{p}<0.05)$. As shown in Figure 4, 1 pM was the optimal concentration for inhibition of caspase- 3 activation and as morphine concentration increased, caspase- 3 activation inhibitory potential of morphine decreased (Fig. 4).

\section{Mitochondrial membrane potential (Rhodamine-123 absorbance)}

Usually, the occurrence of caspase-3 activating apoptosis leads to a change in the mitochondrial membrane potential $(\Delta \varphi \mathrm{m}) . \Delta \varphi \mathrm{m}$ changing of the cells exposed to different treatment media was measured by Rhodamine-123 staining and colorimetry assay at $24 \mathrm{~h}$ after. Based on our results, RH-123 absorption in all of the

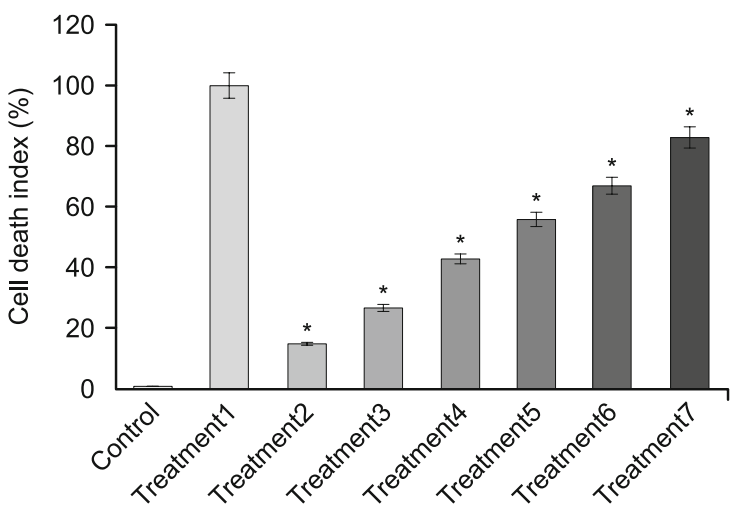

Fig. 3. The effects of different treatments on the cell death on cells. All data represented as the mean \pm SEM $(p<0.05)$.

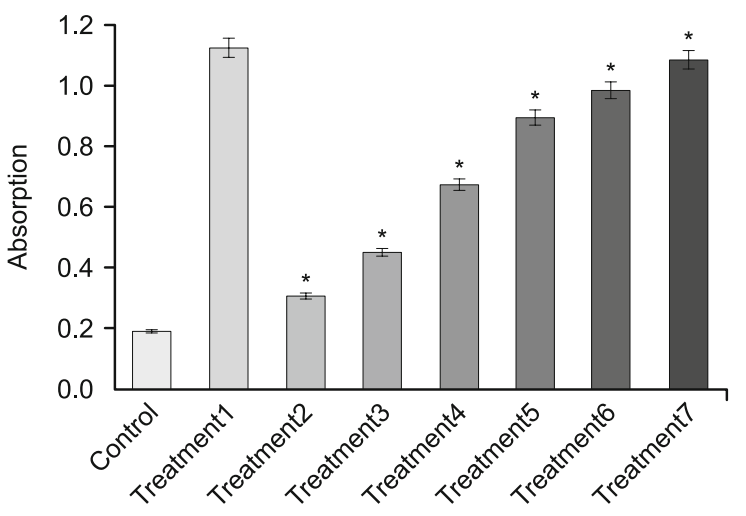

Fig. 4. The effects of different treatments on the caspase- 3 activity on cells. All data represented the mean \pm SEM $(p<0.05)$. 
treatments after $24 \mathrm{~h}$ decreased in comparison to the control treatment $(\mathrm{p}<0.05)$. As shown in Figure 5, the RH-123 absorption in control cells was higher than in the other treatments (treatments $1-7)(\mathrm{p}<0.05)$. RH-123 absorption in treatments $2-7$ were higher in comparison with the treatment 1 , significantly $(\mathrm{p}<0.05)$. Treatment 1 and 2 RH-123 absorption were the lowest and the highest, respectively.

\section{$\left(\mathrm{Ca}^{2+}\right)$ ic and $\left(\mathrm{Ca}^{2+}\right) \mathrm{m}$}

Each treatment had a specific effect on $\left(\mathrm{Ca}^{2+}\right)$ ic and $\left(\mathrm{Ca}^{2+}\right)$ m concentrations in PC12 cells. In 2-7 treatments, the $\left(\mathrm{Ca}^{2+}\right)$ ic were increased compared to the control group $(p<0.05)$ (Fig. 6). Then, after loading the cells with the mitochondrial $\mathrm{Ca}^{2+}$ indicator, a microscope was used to follow up the changes in $\left(\mathrm{Ca}^{2+}\right) \mathrm{m}$ concentrations. A significant decrease in $\left(\mathrm{Ca}^{2+}\right) \mathrm{m}$ concentration in 2-7 treatments compared to the treatment 1 was observed. Highest and lowest $\left(\mathrm{Ca}^{2+}\right)$ ic concentrations were treatment 1 and treatment 2 , respectively. Also, the highest and lowest $\left(\mathrm{Ca}^{2+}\right)$ m concentration were treatment 1 treatment 2 , respectively (Fig. 6).

\section{Measurement of antioxidant enzyme activities}

Each treatment had a specific effect on ROS (.OH) generation in PC12 cells. It is obvious that the overload of ic and mi $\mathrm{Ca}^{2+}$ enhances the cytochrome $\mathrm{c}$ release in the ROS pathway. It is well shown that the events convert in treatments 2-7 compared to the treatment 1 , significantly. In 2-7 treatments, the (.OH) generation was increased compared to the control cells $(\mathrm{p}<0.05)$. In $2-7$ treatments, the $(. \mathrm{OH})$ generation was decreased compared to the treatment $1(\mathrm{p}<0.05)$. The highest and lowest $(. \mathrm{OH})$ generation occurred in treatment 1 and treatment 2 , respectively.

\section{Disscussion}

This study investigated the effect of morphine on nicotineinduced cell death. Some previous studies suggested that nicotine

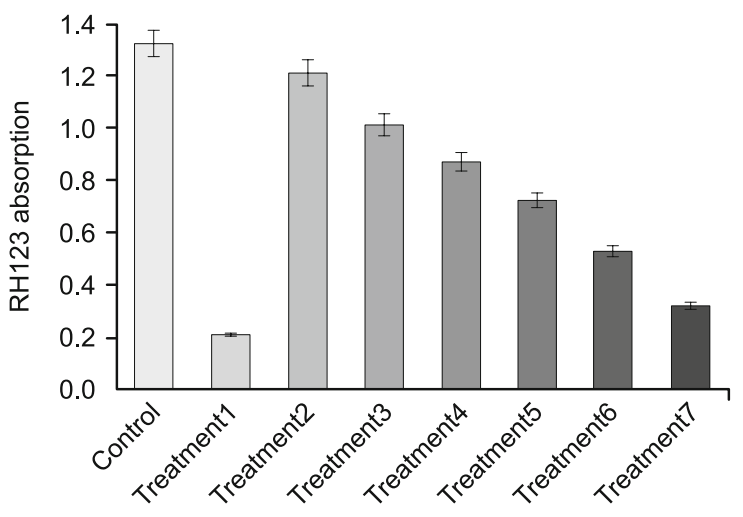

Fig. 5. The effects of different treatments on the Mitochondrial membrane potential (Rhodamine-123 absorbance) in treated PC12 cells. All data represented as the mean \pm SEM $(p<0.05)$. could induce oxidative stress, and also that it could increase the expressions of P53 and P21, which indicates the apoptotic role of this substance $(28,29)$. However, some other studies showed that nicotine increased the ability of angiogenesis in cancer cells, and caused cancer progression by reducing the apoptosis $(30,31)$. These contradictions may be due to differences in computational
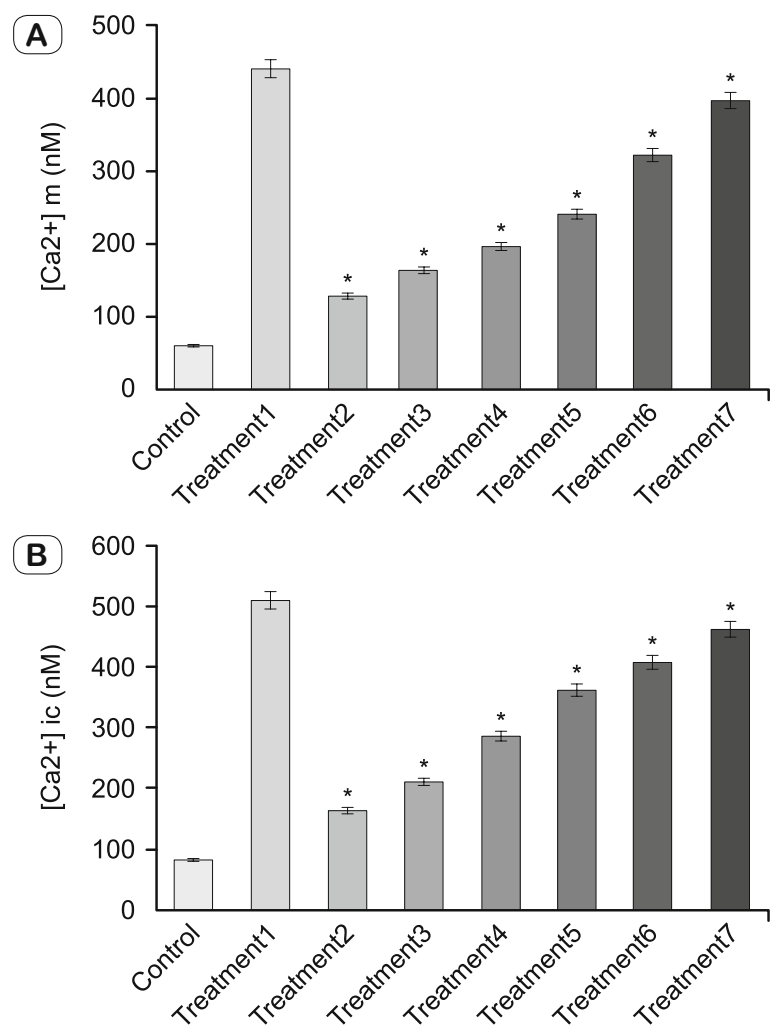

Fig. 6. Determination of $\left(\mathrm{Ca}^{2+}\right) \mathrm{m}(\mathrm{A})$ and $\left(\mathrm{Ca}^{2+}\right)$ ic (B) in different treated cells. All data represented as the mean \pm SEM $(p<0.05)$.

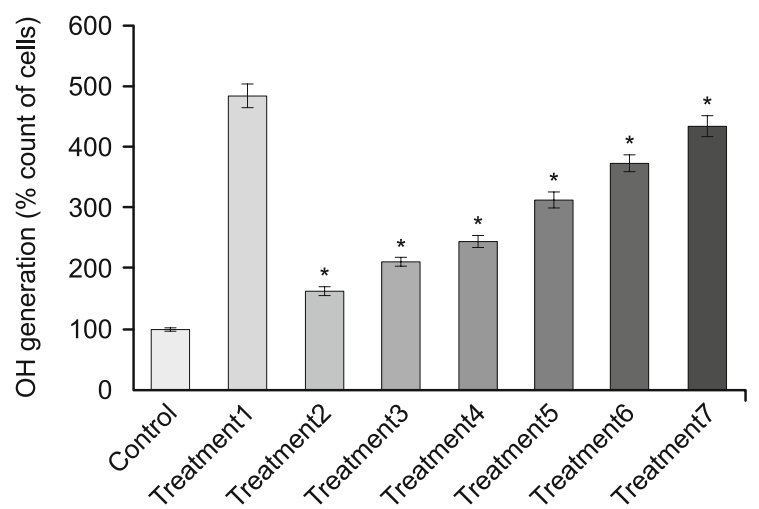

Fig. 7. The antioxidants and reduced agents of endogenous reactive oxygen species (ROS) production in treated cells. All data represented as the mean \pm SEM $(p<0.05)$. 
methods. Perhaps nicotine also has opposite effects in different doses. However, nicotine might have a disruptive effect on neuron cell cultures in high concentration, on the other hand, as shown in our experiments, nicotine at low concentration decreased cell cytotoxicity, intracellular and mitochondria $\mathrm{Ca}^{2+}$ concentration and eventually caspase- 3 activity.

Nicotine-induced an increase in oxidative stress generation, cell cytotoxicity, caspase- 3 activity, intracellular and mitochondrial $\mathrm{Ca}^{2+}$, rhodamine 123 absorption and amount of Tunel positive cells, also induced a decrement in cell viability and mitochondrial membrane potential, in a dose-depended manner. After treatment of the cell culture with morphine, it was obvious that morphine can reduce the apoptotic effects of nicotine in the PC12 cell line, which indicated the anti-apoptotic effects of morphine in a dosedependent manner.

Chang Seong Kim et al. investigation of nicotine effects in $\mathrm{Hu}-$ man proximal tubular epithelial (HK-2) cells revealed that nicotine induced oxidative stress, which enhanced the Erk and JNK signaling pathways phosphorylation and led to the nuclear translocation of the NF- $\kappa \mathrm{B}$ p 65 subunit. Nicotine increased the Bax/Bcl-2 ratio and facilitated the apoptosis. They also suggested that arresting in the G2/M phase of the cell cycle in the HK-2 cells may be due to the presence of nicotine (32).

In-vivo experimental model studies showed that an increased oxidative stress induced by nicotine caused the progression of diabetic nephropathy and chronic kidney disease $(33,34)$. Extra oxidative stress produced by ROS generation up-regulates the extracellular MAPK pathway, which activates the I $\mathrm{B}$ kinase complex that regulates NF- $\kappa \mathrm{B}$. The release of the NF- $\kappa \mathrm{B}$ from $\mathrm{I} \kappa \mathrm{B} \alpha$, makes it move to the nucleus. Above events stimulate the transcription of many proteins that are important for inflammation, apoptosis, and cell proliferation (35). Consistent with these observations, our in vitro experiments demonstrated that the oxidative stress generation due to nicotine treatment was reduced by the low concentrations of morphine.

Moreover, our results indicate that rhodamine123 decreased in nicotine-treated of PC12 cells, in a dose-depended manner. Thus, morphine can increase the rhodamine 123 absorption by the optimal concentration of $1 \mathrm{pM}$. Rhodamine 123 measures the mitochondrial membrane potential $(\Delta \Psi$ mit) and is therefore suitable for demonstrating the sensitive parameters that interpret the efficacy of mitochondrial bioenergetics activity (36-39). The reduction of mitochondrial membrane potential indicates an increased mitochondrial permeability, which results in the release of caspase and nuclease activating proteins and plays a major role in the development of apoptosis. Therefore, a reduction of rhodamine 123 represents an increase in cell apoptosis $(40,41)$ The results of rhodamine 123 measurement showed that morphine inhibited the nicotine-induced apoptosis in a dosedependent way.

According to the previous studies, morphine in the caspase3-dependent pathway induced apoptosis in microglial cells and neurons in the cultures. However, new studies showed that the chronic use of morphine negatively regulates the pre-apoptotic factor Bax in human cultures and rat neurons and by deactivation of caspase-3 and Bad, Fas and FasL as pre-apoptotic factors, can protect the cells from death. Meanwhile, the results of Caspase-3 activity measurements reported the highest amount of protective effect of morphine at $1 \mathrm{pM}$, which confirmed the results of rhodamine 123 measurements $(42,43)$.

Morphine plays an important role in protecting against intracellular oxidative stress and inflammation in the neuroblastoma cell line, peroxynitrite-induced apoptosis in rat infant astrocytes, beta-amyloid toxicity in human neuroblastoma cells (HTB-11) and neurotoxicity of Lipopolysaccharide or 1-methyl-4-phenylpyridinium induced dopaminergic neurotoxicity in rat neuronglial cultures and reduces the cell death induced by ischemia in the hippocampal region (44). Morphine also improves the growth of glomerular cells, breast tumors, and survival of CEMx174 cells by inhibiting P53 signaling $(45,46)$ Morphine protection against apoptosis induced by peroxynitrite in rat neonatal astrocytes is performed by Phosphoinositol kinase 3 (PI3K) (47) and also, the ubiquitin-proteasome complex is involved, reducing the number of oxidized proteins in neuronal protection caused by morphine (48). . Another effect of morphine as an opioid is the regulation of ion channels in the cell membrane. It is obvious that all three opioid receptors are $\mathrm{Ca}^{2+}$-dependent (49).

Morphine, as a potent $\mu$ opioid, activates $\mu$ receptor and is one of the most commonly used drugs for the treatment of chronic pain. Long-term use of this drug leads to physical dependence (50). . Studies showed that an acute morphine treatment resulted in rapid ERK phosphorylation in human neuroblastoma SK-N-SH and SH-SY5Y cells in a short time (several minutes). However, in the long-term use of morphine (3 days), the level of phosphorylation of Erk in SH-SY5Y cells decreases. These findings suggest that ERK-dependent morphine regulate the activation of various neural and non-neuronal cells (51-54).

$\mathrm{N}$-methyl-d-aspartic acid (NMDA) receptor, as a glutamate ionotropic receptor, have an important role in calcium accumulation, which leads to cell death cascade activation (55) Nicotine, in a dose-dependent manner, can activate this receptor and guide the cells to die. On the other hand, it can increase calcium entrance through the $\mathrm{G}$ protein-coupled receptor (GCPR). In this way, PIP2 in the cell membrane divides to IP3 and DAG. DAG inhibits the PKA and activates the PKC. Accumulation of $\mathrm{Ca}^{2+}$ in this way activates the Erk and Erk/Ark pathways, which are the most important in apoptosis (56-59).

\section{Conclusion}

Our results showed that morphine at low concentration could reduce $\mathrm{Ca}^{2+}$ accumulation. It may be due to inactivation of NMDA receptors and GPCRs. These events lead to DAG decrement and PKA activation. PKA inhibits the Erk and Erk/Ark pathways. Also, morphine can protect the cells from nicotine-induced cell death in PC12 cells. Finally, our results revealed that morphine decreased the DNA fragmentation, which occurred through nicotine-induced apoptosis in PC12 cells. 


\section{References}

1. Kumar G, Keserwani S. Mitotraumatism Triggered by Alkaloids (Caffeine and Nicotine) in root meristems of Lathyrus sativus L. (Grass pea). 2016.

2. Hansen SB et al. Structures of Aplysia AChBP complexes with nicotinic agonists and antagonists reveal distinctive binding interfaces and conformations. EMBO J 2005; 24 (20): 3635-3646.

3. Millar NS, Denholm I. Nicotinic acetylcholine receptors: targets for commercially important insecticides. Invertebrate Neuroscience 2007; 7 (1): $53-66$.

4. Pomerleau OF, Pomerleau CS. Neuroregulators and the reinforcement of smoking: towards a biobehavioral explanation. Neurosci Biobehav Rev 1984; 8 (4): 503-513.

5. Pomerleau OF, Rosecrans J. Neuroregulatory effects of nicotine. Psychoneuroendocrinology 1989; 14 (6): 407-423.

6. Keith RJ et al. Nicotine Metabolism in Adults With Type 2 Diabetes. Nicotine Tobacco Res 2017;

7. Marieb EN, Hoehn K. Human anatomy \& physiology. 2007: Pearson Education.

8. Morris PB et al. Cardiovascular effects of exposure to cigarette smoke and electronic cigarettes: clinical perspectives from the Prevention of Cardiovascular Disease Section Leadership Council and Early Career Councils of the American College of Cardiology. J Amer Coll Cardiol 2015; 66 (12): 1378-1391.

9. Chen $\mathbf{H}$ et al. Effect of short-term cigarette smoke exposure on body weight, appetite and brain neuropeptide $\mathrm{Y}$ in mice. Neuropsychopharmacology 2005; 30 (4): 713

10. Audrain-McGovern J, Benowitz N. Cigarette smoking, nicotine, and body weight. Clin Pharmacol Ther 2011; 90 (1): 164-168.

11. Harwani $S$ et al. Cholinergic Stimulation with Nicotine Induces CD68+ Macrophage Infiltration into Kidney and Increases Arterial Pressure in Spontaneously Hypertensive Rats. FASEB J 2015; 29 (Suppl 1): 957.7.

12. Maraqa AD et al. protective effects of vitamin c, vitamin e, and betacarotene against nicotine induced oxidative damage to urinary system of albino rats. Fresenius Environ Bul 2017; 26 (2 A): 1389-1396.

13. Yuan M et al. Nicotine and the adolescent brain. J Physiol 2015; 593 (16): 3397-3412.

14. Joshi M, Tyndale RF. Regional and cellular distribution of CYP2E1 in monkey brain and its induction by chronic nicotine. Neuropharmacology 2006; 50 (5): 568-575.

15. Tewari A et al. White core of cerebellum in nicotine treated rats-a histological study. J Anat Soc India 2010; 59 (2): 150-153.

16. Omotoso GO, Babalola FA. Histological changes in the cerebelli of adult wistar rats exposed to cigarette smoke. Nigerian J Physiol Sci 2014; 29 (1): 43-46.

17. Omotoso GO et al. Moringa oleifera phytochemicals protect the brain against experimental nicotine-induced neurobehavioral disturbances and cerebellar degeneration. Pathophysiology 2018; 25 (1): 57-62.

18. Tegeder I, Geisslinger G. Opioids as modulators of cell death and survival — unraveling mechanisms and revealing new indications. Pharmacol Rev 2004; 56 (3): 351-369.

19. Singhal PC et al. Morphine enhances macrophage apoptosis. J Immunol 1998; 160 (4): 1886-1893.
20. Tegeder I et al. G protein-independent G1 cell cycle block and apoptosis with morphine in adenocarcinoma cells: involvement of p53 phosphorylation. Cancer Res 2003; 63 (8): 1846-1852.

21. Oliveira MT et al. Drugs of abuse induce apoptotic features in PC12 cells. Ann NY Acad Sci 2003; 1010 (1): 667-670.

22. Gupta K et al. Morphine stimulates angiogenesis by activating proangiogenic and survival-promoting signaling and promotes breast tumor growth. Cancer Res 2002; 62 (15): 4491-4498.

23. Shafer T, Atchison W. Transmitter, ion channel and receptor properties of pheochromocytoma (PC12) cells: a model for neurotoxicological studies. Neurotoxicology 1991; 12 (3): 473-492.

24. Seo SR, Seo JT. Calcium overload is essential for the acceleration of staurosporine-induced cell death following neuronal differentiation in PC12 cells. Exp Mol Med 2009; 41 (4): 269.

25. Grynkiewicz G, Poenie M, Tsien RY. A new generation of Ca2+ indicators with greatly improved fluorescence properties. J Biol Chem 1985; 260 (6): 3440-3450.

26. Hoth M, Fanger CM, Lewis RS. Mitochondrial regulation of storeoperated calcium signaling in T lymphocytes. J Cell Biol 1997; 137 (3): 633-648.

27. Abe $\mathrm{S}$ et al. Calcium and reactive oxygen species mediated $\mathrm{Zn2+-}$ induced apoptosis in PC12 cells. J Pharm Sci 2006; 102 (1): 103-111.

28. Zhou $\mathbf{X}$ et al. Nicotine promotes cardiomyocyte apoptosis via oxidative stress and altered apoptosis-related gene expression. Cardiology 2010; 115 (4): 243-250.

29. Berger F, Gage FH, Vijayaraghavan S. Nicotinic receptor-induced apoptotic cell death of hippocampal progenitor cells. J Neurosci 1998; 18 (17): 6871-6881.

30. Heusch WL, Maneckjee R. Signalling pathways involved in nicotine regulation of apoptosis of human lung cancer cells. Carcinogenesis 1998; 19 (4): 551-556.

31. Onoda $\mathbf{N}$ et al. Nicotine affects the signaling of the death pathway, reducing the response of head and neck cancer cell lines to DNA damaging agents. Head Neck 2001; 23 (10): 860-870.

32. Kim CS et al. Nicotine-induced apoptosis in human renal proximal tubular epithelial cells. PloS One 2016; 11 (3): e0152591.

33. Hua $\mathbf{P}$ et al. Nicotine worsens the severity of nephropathy in diabetic mice: implications for the progression of kidney disease in smokers. Amer J Physiol Renal Physiol 2010; 299 (4): F732-F739.

34. Rezonzew G et al. Nicotine exposure and the progression of chronic kidney disease: role of the $\alpha 7$-nicotinic acetylcholine receptor. Amer J Physiol Renal Physiol 2012; 303 (2): F304-F312.

35. Xiantao W et al. The cellular response to oxidative stress: influences of mitogen-activated protein kinase signalling pathways on cell survival. Biochem J 1998; 333 (2): 291-300.

36. Baracca A et al. Rhodamine 123 as a probe of mitochondrial membrane potential: evaluation of proton flux through F0 during ATP synthesis. Biochim Biophys Acta (BBA) Bioenergetics 2003; 1606 (1-3): 137-146.

37. Zanotti A, Azzone GF. Safranine as membrane potential probe in rat liver mitochondria. Arch Biochem Biophys 1980; 201 (1): 255-265.

38. Emaus RK, Grunwald R, Lemasters JJ. Rhodamine 123 as a probe of transmembrane potential in isolated rat-liver mitochondria: spectral and metabolic properties. Biochim Biophys Acta (BBA) Bioenergetics 1986; 850 (3): 436-448. 


\section{$256-262$}

39. Scaduto Jr RC, Grotyohann LW. Measurement of mitochondrial membrane potential using fluorescent rhodamine derivatives. Biophys $\mathrm{J}$ 1999; 76 (1): 469-477.

40. Bernardi P et al. Perspectives on the mitochondrial permeability transition. Biochim Biophys Acta (BBA)-Bioenergetics 1998; 1365 (1-2): 200-206.

41. Matsuyama $\mathrm{S}$ et al. Changes in intramitochondrial and cytosolic $\mathrm{pH}$ : early events that modulate caspase activation during apoptosis. Nature Cell Biol 2000; 2 (6): 318.

42. Nasiraei-Moghadam $S$ et al. Maternal oral consumption of morphine increases $\mathrm{Bax} / \mathrm{Bcl}-2$ ratio and caspase 3 activity during early neural system development in rat embryos. J Mol Neurosci 2010; 41 (1): 156-164.

43. Vucinovic M et al. Maternal and neonatal effects of substance abuse during pregnancy: our ten-year experience. Yonsei Med J 2008; 49 (5): $705-713$.

44. Chen $\mathbf{Q}$ et al. Prolonged morphine application modulates Bax and Hsp70 levels in primary rat neurons. Neurosci Lett 2008; 441 (3): 311-314.

45. Li PF et al. Morphine-promoted survival of CEM $\times 174$ cells in early stages of SIV infection in vitro: involvement of the multiple molecular mechanisms. Toxicol in vitro 2004; 18 (4): 449-456.

46. Patel $\mathbf{J}$ et al. Role of oxidative stress and heme oxygenase activity in morphine-induced glomerular epithelial cell growth. Amer J Physiol Renal Physiol 2003; 285 (5): F861-F869.

47. Kim MS et al. Protective effects of morphine in peroxynitrite-induced apoptosis of primary rat neonatal astrocytes: potential involvement of $\mathrm{G}$ protein and phosphatidylinositol 3-kinase (PI3 kinase). Biochem Pharmacol 2001; 61 (7): 779-786.

48. Fattore $\mathbf{L}$ et al. Astroglial in vivo response to cocaine in mouse dentate gyrus: a quantitative and qualitative analysis by confocal microscopy. Neuroscience 2002; 110 (1): 1-6.
49. North R, Vitek L. A study of the role of cyclic adenosine 3', 5'-monophosphate in the depression by opiates and opioid peptides of excitatory junction potentials in the mouse vas deferens. Brit J Pharmacol 1980; 71 (1): $307-313$.

50. Trapaidze $\mathbf{N}$ et al. Opioid receptor endocytosis and activation of MAP kinase pathway. Mol Brain Res 2000; 76 (2): 220-228.

51. Hawes $\mathbf{J J}$ et al. Galanin protects against behavioral and neurochemical correlates of opiate reward. Neuropsychopharmacology 2008; 33 (8): 1864.

52. Zhai $\mathbf{H}$ et al. Drug-induced alterations in the extracellular signalregulated kinase (ERK) signalling pathway: implications for reinforcement and reinstatement. Cell Mar Mol Neurobiol 2008; 28 (2): 157-172.

53. Lopez-Ilasaca $\mathbf{M}$ et al. Linkage of $\mathrm{G}$ protein-coupled receptors to the MAPK signaling pathway through PI 3-kinase $\gamma$. Science 1997; 275 (5298): 394-397.

54. Valjent $\mathbf{E}$ et al. Addictive and non-addictive drugs induce distinct and specific patterns of ERK activation in mouse brain. Eur $\mathrm{J}$ Neurosci 2004; 19 (7): 1826-1836.

55. Zhang $\mathrm{S}$ et al. Calmodulin mediates calcium-dependent inactivation of N-methyl-D-aspartate receptors. Neuron 1998; 21 (2): 443-453.

56. Smith FL, Lohmann AB, Dewey WL. Involvement of phospholipid signal transduction pathways in morphine tolerance in mice. Brit J Pharmacol 1999; 128 (1): 220-226.

57. West AE et al. Calcium regulation of neuronal gene expression. Proc Nat Acad Sci 2001; 98 (20): 11024-11031.

58. Kanashiro CA, Khalil RA. Signal transduction by protein kinase C in mammalian cells. Clin Exp Pharmacol Physiol 1998; 25 (12): 974-985.

59. Berhow MT, Hiroi N, Nestler EJ. Regulation of ERK (Extracellular SignalRegulated Kinase), Part of the Neurotrophin Signal Transduction Cascade, in the Rat Mesolimbic Dopamine System by Chronic Exposure to Morphine or Cocaine. J Neurosci 1996; 16 (15): 4707-4715.

Received December 26, 2018. Accepted February 5, 2019. 